\title{
Investigation of the Current Situation and Countermeasures of Kindergarten Life Education
}

\author{
WeiSun, YingchunZhou
}

School of Pre-school Education of Chongqing University of Education, Chongqing 400067, China

Workemail:sunwei@cque.edu.cn

\begin{abstract}
Children's self-awareness, social cognition, and life values, etc. have been developed, and life experience and sense of identity of life value are very important for the growth of the whole life. Therefore, life education should be carried out from an early age to guide children to love and cherish life, use positive energy to inspire children's life spirit, and shape children's positive outlook on life and correct attitude towards life. This research analyzes the current situation of kindergarten life education from the aspects of the life attitude, life education attitude of the kindergarten teachers and solutions for the questions. In addition, it also includesthe frequency, content, ways andmethods, and principles of the kindergarten life education. on this basis, the research provides a reference for children's life education to promote the healthy development of children.
\end{abstract}

Keywords : Life education; Analysis of current situation; Countermeasures

\section{INTRODUCTION}

Self-awareness, social cognition, life cognition and other aspects of children have been developed to a certain degree in the preschool period, and life experience and sense of identity of life value in the preschool period are very important. Therefore, in the historical background where life education is advocated, preschool education, as the starting stage of life-long education, should take on the important task of life education. At present, many international and domestic kindergartens have incorporated life education into a specialized course system and developed corresponding resource systems. Although the focus is different, they are committed to stimulating the potential of life, improving the quality of life, and feeling the beauty of life. In our China's Outline for National Medium- and Long-term Plan for Educational Reform and Development (2010-2020) and Early Learning and Development Guideline at 3-6 Years Old and other national policy orientations, the focus on the children's life experience and value is advocated. There are few surveys and analyses on the development of life education in kindergartens in China. On this basis, this research analyzes the dilemmas and difficulties faced by the kindergarten in life education through questionnaires, and proposes corresponding implementation countermeasures for the problems and the causes of the problems, in order to provide some practical suggestions for kindergarten life education. Among them, the children's life education here refers to the education activity in which kindergarten teachers guide the 3-6 year-old children in preliminary understanding of the life process, so that the children have a preliminary life awareness, and understand life hardships, perceive the value and significance of life, learn to protect themselves, learn to respect and love life entities, and finally form a correct and positive outlook on life.

\section{RESEARCH OBJECT AND METHODS}

\subsection{Research object}

A total of 188 questionnaires were sent out and recovered among the kindergarten teachers in Chongqing. the recovery rate was $100 \%$; 171 valid questionnaires were recovered, and the questionnaire validity rate was $91 \%$. Among them, 143 were female teachers and 28 were male teachers. Their educational backgrounds are mainly junior college and bachelor's degree.

\subsection{Research methods}

2.2.1 Literature method. On the basis of collecting, reading, sorting out, analyzing and comparing the existing literature, we can clearly judge and analyze the research trends and development of domestic and foreign children life education, providing support for the research.

\subsubsection{Questionnaire survey method. This research} uses the questionnaire prepared by Xu Lanlan (2017) [1], which is composed of 25 items, including 5 basic information parts and 20 text parts. On this basis, necessary adjustment is made based on the actual situation of this research. Among them, there are 2 first-level dimensions, namely life educational quality for kindergarten teachers and kindergarten life education courses. The former includes 3 second-level dimensions including life attitude, life education attitude, and problem solving method; the latter includes 5 second-level dimensions including life education frequency, objectives, contents, methods and approaches, and education principles; the reliability and validity of the questionnaire are all above 0.8 , which meets the requirements of the tool.

2.2.3 Interviewing method. In order to further understand the current situation of life education in kindergartens and make up for the shortcomings of questionnaire surveys, some kindergarten teachers were 
interviewed to know the understanding of the meaning of life education and the specific implementation of life education among kindergarten teachers.

\section{RESEARCH RESULTS}

\subsection{Overall situation of kindergarten life education}

It can be seen from Table 1 that the mean values of the 8 second-level dimensions of kindergarten life education are life education principles, contents, objectives, development frequency, life attitude, problem solving method, life education attitude, life education methods and approaches in order from high to low. The mean value of life attitude and life education attitude is not ideal, indicating that kindergarten teachers have different understandings of life and life education; among them, the mean value of life education methods and approaches is the smallest. The life education methods and approaches of kindergarten are single, and the effect of life education activities is not ideal.

TABLE 1 DESCRIPTIVE STATISTICS OF KINDERGARTEN LIFE EDUCATION

\begin{tabular}{|c|c|c|c|c|c|c|}
\hline First-level dimension & Second-level dimension & $\mathbf{N}$ & Min. & Max. & Mean & $\begin{array}{l}\text { Standard } \\
\text { deviation }\end{array}$ \\
\hline & Life attitude & 171 & 1.000 & 4.200 & 2.123 & 0.422 \\
\hline $\begin{array}{l}\text { Kindergarten teachers' } \\
\text { life }\end{array}$ & Life education attitude & 171 & 1.000 & 4.800 & 1.997 & 0.646 \\
\hline \multirow[t]{2}{*}{ Educational quality } & Problem solving methods & 171 & 1.000 & 5.000 & 2.000 & 0.939 \\
\hline & Frequency of life education & 171 & 1.000 & 4.000 & 2.825 & 1.048 \\
\hline Kindergarten life & Life educational objectives & 171 & 1.364 & 8.273 & 4.266 & 1.572 \\
\hline \multirow[t]{3}{*}{ Educational courses } & Life education content & 171 & 2.364 & 15.273 & 7.646 & 2.745 \\
\hline & $\begin{array}{l}\text { Life education methods and } \\
\text { approaches }\end{array}$ & 171 & 0.273 & 1.273 & 0.722 & 0.183 \\
\hline & Principles of life education & 171 & 3.364 & 20.273 & 10.530 & 3.588 \\
\hline Total & & 171 & 15.455 & 63.091 & 32.109 & 8.013 \\
\hline
\end{tabular}

\section{2 difference analysis}

\subsubsection{Test of differences in life education of} kindergarten teachers of different genders

It can be seen from Table 2 that life education has extremely obvious differences in the gender of kindergarten teachers $(t=-3.179, p=0.002)$, in which life attitude, life education methods and approaches have reached the level of 0.05 , indicating that there are obvious differences in the gender of kindergarten teachers, while life education attitudes, objectives, contents, and principles have reached the level of 0.01 , indicating that there are extremely obvious differences in the gender of kindergarten teachers. Male kindergarten teachers $(27.82$ $\pm 7.30)$ are obviously lower than female kindergarten teachers $(32.95 \pm 7.90)$ in the frequency, objectives, contents and principles of life education.

TABLE 2 TEST OF DIFFERENCES IN LIFE EDUCATION OF KINDERGARTEN TEACHERS OF DIFFERENT GENDERS

\begin{tabular}{lllll}
\hline Dimension & Male $(\mathbf{M} \pm$ SD) & Female $(\mathbf{M} \pm$ SD) & t & p \\
\hline Life attitude & $2.29 \pm 0.45$ & $2.09 \pm 0.41$ & 2.258 & 0.025 \\
Life education attitude & $2.29 \pm 0.62$ & $1.94 \pm 0.64$ & 2.716 & 0.007 \\
Problem solving methods & $2.29 \pm 1.08$ & $1.94 \pm 0.90$ & 1.565 & 0.127 \\
Frequency of life education & $2.68 \pm 0.90$ & $2.85 \pm 1.07$ & -0.904 & 0.371 \\
Life educational objectives & $3.44 \pm 1.57$ & $4.43 \pm 1.53$ & -3.138 & 0.002 \\
Life education content & $6.01 \pm 2.57$ & $7.97 \pm 2.67$ & -3.575 & 0.000 \\
Life education methods and approaches & $0.65 \pm 0.20$ & $0.74 \pm 0.18$ & -2.337 & 0.021 \\
\hline
\end{tabular}




\begin{tabular}{lllll}
\hline Principles of life education & $8.19 \pm 3.44$ & $10.99 \pm 3.44$ & -3.940 & 0.000 \\
Total & $27.82 \pm 7.30$ & $32.95 \pm 7.90$ & -3.179 & 0.002 \\
& & & & \\
\hline
\end{tabular}

3.2.2 Test of differences in life education of kindergarten teachers of different school ages According to the results of the one-way analysis of variance, life attitude, life education attitude and problem solving methods have reached the level of 0.01 , indicating that there are extremely obvious differences in the school age of kindergarten teachers. Among them, teachers with more than 20 years of teaching experience are the highest in these three dimensions, followed by teachers with 10-20 years of teaching experience; teachers with 4-9 years of teaching experience and those with less than 3 years of teaching experience are relatively low. There are no obvious differences in life education frequency, objectives, contents, methods and approaches, and principles in the school age of kindergarten teachers $(\mathrm{P}>$ 0.05). What is different from teachers' life educational quality is that at most second-level dimensions in the first-level dimension of life education curriculum, teachers with less than 3 years of teaching experience and 4-9 years of teaching experience performance better than teachers with longer teaching age.

\section{TABLE 3 TEST OF DIFFERENCES IN LIFE EDUCATION OF KINDERGARTEN TEACHERS OF DIFFERENT SCHOOL AGES}

\begin{tabular}{|c|c|c|c|c|c|c|}
\hline Dimension & $\begin{array}{l}\text { Under } 3 \text { years } \\
(\mathrm{M} \pm \mathrm{SD})\end{array}$ & $\begin{array}{l}\text { 4-9 years } \\
(\mathrm{M} \pm \mathrm{SD})\end{array}$ & $\begin{array}{c}\text { 10-20 years } \\
(\mathrm{M} \pm \mathrm{SD})\end{array}$ & $\begin{array}{l}\text { Over } 20 \text { years } \\
(\mathrm{M} \pm \mathrm{SD})\end{array}$ & $\mathbf{F}$ & $\mathbf{p}$ \\
\hline Life attitude & $2.09 \pm 0.32$ & $2.05 \pm 0.34$ & $2.28 \pm 0.52$ & $2.54 \pm 0.85$ & 5.634 & 0.001 \\
\hline Life education attitude & $1.81 \pm 0.43$ & $1.85 \pm 0.47$ & $2.57 \pm 0.78$ & $3.01 \pm 0.92$ & 24.684 & 0.000 \\
\hline Problem solving methods & $1.87 \pm 0.79$ & $1.76 \pm 0.67$ & $2.43 \pm 0.95$ & $3.60 \pm 1.58$ & 17.122 & 0.000 \\
\hline Frequency of life education & $2.84 \pm 1.08$ & $2.84 \pm 1.08$ & $2.78 \pm 1.00$ & $2.70 \pm 0.82$ & 0.069 & 0.976 \\
\hline Life educational objectives & $4.59 \pm 1.58$ & $4.07 \pm 1.45$ & $4.04 \pm 1.57$ & $4.25 \pm 2.20$ & 1.426 & 0.237 \\
\hline Life education content & $8.08 \pm 2.80$ & $7.34 \pm 2.48$ & $7.30 \pm 2.93$ & $8.05 \pm 3.79$ & 1.029 & 0.381 \\
\hline Life education methods and approaches & $0.74 \pm 0.18$ & $0.71 \pm 0.18$ & $0.70 \pm 0.17$ & $0.75 \pm 0.25$ & 0.650 & 0.584 \\
\hline Principles of life education & $11.28 \pm 3.70$ & $10.15 \pm 3.20$ & $9.78 \pm 3.86$ & $10.35 \pm 4.62$ & 1.567 & 0.199 \\
\hline \multicolumn{7}{|l|}{ Total } \\
\hline & $33.30 \pm 7.80$ & $30.76 \pm 7.22$ & $31.89 \pm 8.37$ & $35.23 \pm 12.57$ & 1.712 & 0.166 \\
\hline
\end{tabular}

\subsubsection{Test of differences in life education of} kindergarten teachers of different educational backgrounds

It can be seen from Table 4 that life education has extremely obvious differences in the educational background of kindergarten teachers $(\mathrm{F}=4.230, \mathrm{p}=$ $0.007)$, in which life education attitude has reached 0.01 , while problem solving methods, life education contents and principles have reached 0.05 . The performance of teachers of various educational backgrounds is graduate students, undergraduates, below junior colleges, and junior colleges in order from high to low 
TABLE 4 TEST OF DIFFERENCES IN LIFE EdUCATION OF KINDERGARTEN

TEACHERS OF DIFFERENT EDUCATIONAL BACKGROUNDS

\begin{tabular}{lllllll}
\hline Dimension & $\begin{array}{l}\text { Below junior } \\
\text { college } \\
(\mathrm{M} \pm \mathrm{SD})\end{array}$ & $\begin{array}{c}\text { Junior college } \\
(\mathrm{M} \pm \mathrm{SD})\end{array}$ & $\begin{array}{c}\text { Undergraduate } \\
(\mathrm{M} \pm \mathrm{SD})\end{array}$ & $\begin{array}{c}\text { Postgraduate } \\
(\mathrm{M} \pm \mathrm{SD})\end{array}$ & F & p \\
\hline $\begin{array}{l}\text { Life attitude } \\
\text { Life education }\end{array}$ & $2.31 \pm 0.55$ & $2.08 \pm 0.41$ & $2.11 \pm 0.34$ & $2.47 \pm 1.05$ & 2.185 & 0.092 \\
attitude & $1.98 \pm 0.59$ & $1.89 \pm 0.49$ & $2.91 \pm 1.33$ & 8.858 & 0.000 \\
$\begin{array}{l}\text { Problem solving } \\
\text { methods }\end{array}$ & $2.44 \pm 1.67$ & $2.04 \pm 0.93$ & $1.87 \pm 0.77$ & $2.83 \pm 1.47$ & 3.011 & 0.032 \\
$\begin{array}{l}\text { Frequency of life } \\
\text { education }\end{array}$ & $2.67 \pm 0.87$ & $2.97 \pm 1.09$ & $2.73 \pm 1.03$ & $2.83 \pm 1.17$ & 0.736 & 0.532 \\
$\begin{array}{l}\text { Life educational } \\
\text { objectives }\end{array}$ & $4.26 \pm 1.72$ & $4.09 \pm 1.40$ & $4.30 \pm 1.64$ & $5.77 \pm 1.71$ & 2.158 & 0.095 \\
$\begin{array}{l}\text { Life education } \\
\text { content }\end{array}$ & $7.26 \pm 3.02$ & $7.36 \pm 2.36$ & $7.68 \pm 2.85$ & $10.94 \pm 3.27$ & 3.310 & 0.022 \\
$\begin{array}{l}\text { Life education } \\
\text { methods and } \\
\text { approaches }\end{array}$ & $0.71 \pm 0.19$ & $0.72 \pm 0.16$ & $0.72 \pm 0.20$ & $0.77 \pm 0.30$ & 0.171 & 0.916 \\
$\begin{array}{l}\text { Principles of life } \\
\text { education }\end{array}$ & $9.26 \pm 2.98$ & $10.11 \pm 2.98$ & $10.70 \pm 3.83$ & $14.61 \pm 4.71$ & 3.476 & 0.017 \\
\begin{tabular}{l} 
Total \\
\hline
\end{tabular} & $31.55 \pm 8.45$ & $31.36 \pm 6.95$ & $31.99 \pm 8.11$ & $43.13 \pm 10.89$ & 4.230 & 0.007 \\
\hline
\end{tabular}

3.2.4 Test of differences in life education of kindergarten teachers of different phases of studying

From the one-way analysis of variance, we can see that there is no obvious difference in life education in the phase of studying of kindergarten teachers $(\mathrm{F}=0.568, \mathrm{p}=$
0.568), indicating that the life education activities of the three age stages show consistency, but the frequency of life education has reached the level of 0.01 ; they are top class, primary class, and mid-class in order from high to low.

TABLE 5 TEST OF DIFFERENCES IN LIFE EdUCATION OF KINDERGARTEN TEACHERS OF DIFFERENT PHASES OF STUDYING

\begin{tabular}{|c|c|c|c|c|c|}
\hline Dimension & $\begin{array}{ll}\text { Primary } & \text { class } \\
(\mathrm{M} \pm \mathrm{SD}) & \end{array}$ & $\begin{array}{l}\text { Mid-class } \\
(\mathrm{M} \pm \text { SD })\end{array}$ & $\begin{array}{ll}\text { Top } & \text { class } \\
(\mathrm{M} \pm \mathrm{SD}) & \end{array}$ & $\mathbf{F}$ & $\mathbf{p}$ \\
\hline Life attitude & $2.09 \pm 0.34$ & $2.09 \pm 0.38$ & $2.19 \pm 0.52$ & 1.080 & 0.342 \\
\hline Life education attitude & $2.00 \pm 0.65$ & $1.95 \pm 0.60$ & $2.06 \pm 0.70$ & 0.413 & 0.662 \\
\hline Problem solving methods & $2.00 \pm 0.98$ & $1.90 \pm 0.78$ & $2.13 \pm 1.08$ & 0.910 & 0.405 \\
\hline Frequency of life education & $3.00 \pm 1.04$ & $2.51 \pm 1.02$ & $3.07 \pm 1.01$ & 5.537 & 0.005 \\
\hline Life educational objectives & $4.38 \pm 1.38$ & $4.20 \pm 1.60$ & $4.25 \pm 1.71$ & 0.199 & 0.820 \\
\hline Life education content & $7.87 \pm 2.29$ & $7.56 \pm 2.88$ & $7.57 \pm 2.95$ & 0.221 & 0.802 \\
\hline $\begin{array}{l}\text { Life education methods and } \\
\text { approaches }\end{array}$ & $0.73 \pm 0.14$ & $0.71 \pm 0.20$ & $0.73 \pm 0.20$ & 0.175 & 0.839 \\
\hline Principles of life education & $10.87 \pm 2.74$ & $10.46 \pm 3.89$ & $10.32 \pm 3.86$ & 0.317 & 0.729 \\
\hline Total & $32.95 \pm 6.55$ & $31.38 \pm 8.34$ & $32.33 \pm 8.77$ & 0.568 & 0.568 \\
\hline
\end{tabular}




\section{DISCUSSION AND ANALYSIS}

\subsection{The content is diverse, but the overall effect is not ideal}

When kindergarten teachers carry out life education, the content selection and principles to follow are relatively rich and varied, and the setting of objectives is relatively comprehensive. However, the scores of life attitude, life education attitude, problem solving methods and frequency of life education of kindergarten teachers are not ideal. Many preschool teachers are not focused on life itself but pay more attention to the superficial phenomenon of preschool children's lives. They only care about whether the children are alive (or only focus on the safety of the children), but do not have a deep understanding of being alive and the essence of a child's life. Some researchers also pointed out that $59.8 \%$ of kindergarten teachers cannot fully understand the content of preschool life education ${ }^{[2]}$.

\subsection{The gender imbalance of kindergarten teachers affects the quality of life education}

In terms of life educational quality, male teachers are better than female teachers, but in specific life education operation courses, female teachers are better than male teachers. This is related to the cognitive styles, personality characteristics, emotional and affective states of teachers of different genders, and is also related to the gender structure of kindergarten teachers in China. The gender ratio of kindergarten teachers in China is very different, and most of them are female teachers. According to the Education Statistical Yearbook of China, as of 2018, there were 2,432,138 full-time teachers in preschool education, including 2,378,291 female full-time teachers, accounting for $97.79 \%$; and 53,847 male full-time teachers, accounting for $2.21 \%{ }^{[3]}$.

\subsection{Experiential and novice teachers perform well, with fault phenomena in the middle}

Teachers just starting work are full of expectations for their careers, try their best to do everything, and have a good attitude to life; while kindergarten teachers who have been working for 4-9 years will gradually be in a job tiring period, losing freshness in the daily work of kindergarten, and having a declined working level; kindergarten teachers who have been working for 10-20 years may face a stagnation period in their careers, and there will be confusion, lack of goals and motivations, and even negative emotions, resulting in a negative life attitude; kindergarten teachers who have been working for over 20 years may have broken through the work bottleneck, have more good life education experience, can better develop life education courses and can better implement and use the courses. As their psychological development and high proficiency in work, they do not face the pressure of various competitions of titles, and they will gradually concentrate on and enjoy their own careers and life, so the level of life education is obviously improved.

\subsection{Educational backgrounds are basically positively related to life education, which is noteworthy}

To a certain extent, educational backgrounds can reflect the growth, educational environment, and professional qualities of kindergarten teachers. Different world outlooks, outlooks on life, and educational outlooks will be formed. People with excellent educational backgrounds usually have better self-efficacy and stronger self-control and adjustment capabilities. Most scholars at home and abroad believe that the individual's education level has a positive relationship with life attitude. Highly educated people often have a higher level of understanding and acceptance, more easily accept birth, death, illness and old age, and have a good life attitude. Nelson (2001), et al. deeply analyzed the relationship between education level and death attitude, and proved that people with low education level are easy to avoid death-related topics, and people with high education level are more inclined to neutral acceptance ${ }^{[4]}$. This is consistent with the analysis of the attitude towards life in this research. In terms of time, from 2001 to 2011 and to 2020, the results of impact of educational backgrounds on life education are consistent.

\subsection{Life education does not pay attention to the individual differences of preschool children, and there is a trend of "convergence"}

The kindergarten teachers do not set the corresponding life educational objectives, contents, methods and approaches for the children of different ages. The reason is that kindergarten teachers do not understand the physical and mental development laws and learning characteristics of preschool children, and they do not have enough knowledge and understanding of life education. They do not have enough life education skills reserves, nor do they have the consciousness and ability to develop life education courses. On the other hand, kindergartens pay little attention to the integrity of life education. The lack of resources to implement life education, lack of approaches, and insufficient investment in the life education sector in terms of funds and time prevent kindergarten teachers from better carrying out life education.

\section{EDUCATIONAL SUGGESTIONS}

\subsection{Macroscopically grasp the design to improve the quality of life education teaching staff}

Teachers are the supporters, promoters and guides of children's learning, and they play an important role in life education. Teachers' outlook on life affects children's perception of life and death. The successful implementation of life education is inseparable from the active participation and cooperation of teachers, and the quality of teachers determines the success or failure of life education to a large extent, so we should pay attention to 
and strengthen the training of life education teachers. Life educational quality can be improved by conducting life education teaching research meetings and teaching observation meetings, providing sufficient learning resources, and establishing learning exchange platforms; setting up life education related courses, or setting up skills competitions related to life education for normal students. More importantly, kindergarten teachers should uphold the concept of lifelong learning, enrich their life experience, and deliver positive energy of life value.

\subsection{Guided by the concept of Madhyamaka, constructing perfect life educational objectives and contents}

The ultimate goal of life education is to cultivate children's life consciousness, emotion, will and behavior, which is specifically manifested in fully understanding life, understanding the value of life, cherishing themselves, showing compassion to others, and caring for society; treating life correctly, respecting life, and cultivating children's positive life attitude; cultivating children's life will and behavior, learning life-protection skills, learning to love and respect other lives in nature, etc.; establishing diversified life education perspectives, and choosing life education content suitable for children's development characteristics; carrying out life education in life understanding, life emotion, safety and health, etc., penetrating the life emotion education, and raising the content of education to cherishing of life and respecting of life; developing children life education courses with local characteristics according to the situation of teachers, children, local culture, etc.

\subsection{Microscopically enforce implementation for development of diverse life education methods and approaches}

Life experience shall be taken as the basic means of implementation of life education for children. In a real life scenario, we face life directly, intuitively feel, experience, appreciate, and understand life activities with life. We can allow preschool children to experience and think in the context through course penetration teaching, theme activities, game activities, corner activities and social practice activities. At the same time, the teaching methods should be rich and varied, and teaching can be carried out through appreciation teaching, visiting and interviews, role playing, telling, exploration and cooperation, reading guidance, etc. In addition, kindergarten teachers should grasp the scale of random education, be good at seizing the opportunity of life education in a day's life, catch the interest of children in time, design activity plans to extend the interest of children, and deepen children's understanding.

\section{CONCLUSION}

The survey found that with regard to the Current Situation and Countermeasures of Kindergarten Life Education, we can reach the following main
conclusions:In the mass, the content is diverse, but the overall effect is not ideal.The gender imbalance of kindergarten teachers affects the quality of life education. Experiential and novice teachers perform well, with fault phenomena in the middle.Educational backgrounds are basically positively related to life education, which is noteworthy.Life education does not pay attention to the individual differences of preschool children, and there is a trend of "convergence".

\section{ACKNOWLEDGMENT}

This paper is the staged research achievement of 2019 School-level Teaching Reform Project of Chongqing University of Education: "Practice Study on the Integration of "Preschool + Art" Segmented Classroom Teaching Reform" (JG201921) and Science and Technology Collaborative Innovation Platform "Family Education Research Center for Children Aged 0-6" (16xjpt03) of Chongqing University of Education.

\section{REFERENCES}

[1] Xu, L.L. (2017). Research on the Current Situation and Countermeasures of Kindergarten Life Education. China West Normal University.

[2] Deng, Y. (2014). The Preliminary Exploration of the Life Education of Children - The Analysis of The Kindergarten Outline, The Present Situation Investigation and The Curriculum Idea about The Life Education of Children. Hohhot: Inner Mongolia Normal University.

[3] Education Statistical Yearbook of China. Committee of Education Statistical Yearbook of China, 2018.

[4] Nelson,L.D.Structual conductiveness,personality characteristics and death anxiety.Omega

(Westport) .2001,43,4:331-347.

[5] Pan,D.1., Xia,C.(2016).Onthe Philosophical Foundation of Preschool Children Life Education . Education and Teaching Research, 30 (01): 116-122.

[6] Zhang,W.M., Wang,Bing.(2019).Examining and Constructing Kindergarten Education from the Perspective of Life Education . Studies in Preschool Education, 2019 (04): 57-65.

[7] Sultan Ayaz-Alkaya PhD,Handan Terzi 
MSN,Betül Işık MSN,Ebru Sönmez MSN. A healthy lifestyle education programme for health literacy and health-promoting behaviour:A pre-implementation and post-implementation study. International Journal of Nursing Practice,2020,26(2).

[8] Xu, S.P. (2002). Life Education and Level Analysis . Chinese Journal of Education, (04): 7-10.
[9]Sultan Ayaz-Alkaya PhD,Handan Terzi MSN, Betül Işık MSN, Ebru Sönmez MSN. A healthy lifestyle education programme for health literacy and health-promoting behaviours: A pre-implementation and post-implementation study. International Journal of Nursing Practice,2020,26(2). 